Boston University School of Law

Scholarly Commons at Boston University School of Law

Faculty Scholarship

Winter 2014

\title{
Toward a Regulatory Framework for Third-Party Funding of Litigation
}

Keith N. Hylton

Boston University School of Law

Follow this and additional works at: https://scholarship.law.bu.edu/faculty_scholarship

Part of the Law and Economics Commons, and the Litigation Commons

\section{Recommended Citation}

Keith N. Hylton, Toward a Regulatory Framework for Third-Party Funding of Litigation , in 63 DePaul Law Review 527 (2014).

Available at: https://scholarship.law.bu.edu/faculty_scholarship/183

This Article is brought to you for free and open access by Scholarly Commons at Boston University School of Law. It has been accepted for inclusion in Faculty Scholarship by an authorized administrator of Scholarly Commons at Boston University School of Law. For more information, please contact lawlessa@bu.edu. 


\section{HEINONLINE}

DATE DOWNLOADED: Tue Sep 20 21:05:21 2022

SOURCE: Content Downloaded from HeinOnline

Citations:

Bluebook 21st ed.

Keith N. Hylton, Toward a Regulatory Framework for Third-Party Funding of Litigation, 63 DEPAUL L. REV. 527 (2014).

ALWD 7th ed.

Keith N. Hylton, Toward a Regulatory Framework for Third-Party Funding of Litigation, 63 DePaul L. Rev. 527 (2014).

APA 7th ed.

Hylton, K. N. (2014). Toward regulatory framework for third-party funding of litigation. DePaul Law Review, 63(2), 527-546.

Chicago 17th ed.

Keith N. Hylton, "Toward a Regulatory Framework for Third-Party Funding of Litigation," DePaul Law Review 63, no. 2 (Winter 2014): 527-546

McGill Guide 9th ed.

Keith N. Hylton, "Toward a Regulatory Framework for Third-Party Funding of Litigation" (2014) 63:2 DePaul L Rev 527.

AGLC 4th ed.

Keith N. Hylton, 'Toward a Regulatory Framework for Third-Party Funding of Litigation' (2014) 63(2) DePaul Law Review 527

MLA 9th ed.

Hylton, Keith N. "Toward a Regulatory Framework for Third-Party Funding of Litigation." DePaul Law Review, vol. 63, no. 2, Winter 2014, pp. 527-546. HeinOnline.

OSCOLA 4th ed.

Keith N. Hylton, 'Toward a Regulatory Framework for Third-Party Funding of Litigation' (2014) 63 DePaul L Rev 527

Provided by:

Fineman \& Pappas Law Libraries

-- Your use of this HeinOnline PDF indicates your acceptance of HeinOnline's Terms and Conditions of the license agreement available at https://heinonline.org/HOL/License

-- The search text of this PDF is generated from uncorrected OCR text.

-- To obtain permission to use this article beyond the scope of your license, please use: Copyright Information 


\title{
TOWARD A REGULATORY FRAMEWORK FOR THIRD.PARTY FUNDING OF LITIGATION
}

\author{
Keith N. Hylton*
}

\begin{abstract}
Because third-party funding and sales of legal rights are equivalent in terms of their economics, I examine arrangements in which thirdparty sales of legal rights are permitted today; those arrangements include waiver, subrogation, and settlement agreements. These existing arrangements provide valuable lessons for the appropriate regulatory approach to third-party financing of litigation.
\end{abstract}

\section{INTRODUCTION}

Historically, common law has prohibited third-party funding of litigation through doctrines such as champerty, maintenance, and barratry. ${ }^{1}$ These prohibitions, based largely on ethical concerns, ${ }^{2}$ still exist in many common law jurisdictions today, ${ }^{3}$ though there is little evidence of enforcement. Firms offering lawsuit loans are not hard to find in most American states. One could take this, along with the failures of drug interdiction and economic sanctions, as yet another piece of evidence that the law shrinks in the face of strong economic incentives. For the most part, using the law to prevent willing buyers and sellers from making deals is a fool's errand.

This Article has little to say about the law on third-party funding of litigation; it focuses instead on the economics of third-party funding relationships. ${ }^{4}$ The traditional ethical objections to third-party funding have suffered from a lack of clarity and precision. ${ }^{5}$ I proceed on the view that in order to identify what is wrong with litigation funding, we first have to understand how it affects the incentives of actors in the litigation system. I present two arguments: first, that third-party

* William Fairfield Warren Distinguished Professor, Boston University, and Professor of Law, Boston University School of Law. E-mail: knhylton@bu.edu. This Article was prepared for the 19th Annual Clifford Symposium on Tort Law and Social Policy at DePaul University. I thank symposium participants and symposium discussant, Andrew Gold, for comments.

1. 4 William Blackstone, Commentaries *134-35.

2. See id.

3. Anthony J. Sebok, The Inauthentic Claim, 64 VAND. L. REv. 61, 98-99, 99 n.162, 107 \& n.190 (2011).

4. This Article builds on the argument in Keith N. Hylton, The Economics of Third-Party Financed Litigation, 8 J.L. Econ. \& PoL'y 701 (2012).

5. Id. at 705 . 
funding and sales of legal rights are equivalent in terms of their economics; and second, that the existing arrangements in which thirdparty sales of legal rights are permitted-waiver, subrogation, and settlement agreements-provide valuable lessons for the appropriate regulatory approach to litigation funding.

The economic equivalence of litigation funding and sales of legal rights is important because it helps identify the source of what is objectionable (if anything) in litigation funding. In essence, the ethically based objections are grounded in objections to the alienation of legal rights. ${ }^{6}$ However, legal rights are sold today, and have been for a long time, as commentators have observed in the case of settlement. ${ }^{7}$ The mere equivalence of funding and sales, though a useful heuristic to discover the ethical basis of objections, is insufficient by itself to support those objections. A deeper analysis of how transfers of legal rights could reduce society's welfare is necessary.

The welfare analysis undertaken here suggests that regulation should apply different rules to third-party litigation funding in the context of unmatured legal rights-rights to sue for probable injuries that have yet to occur-and in the context of matured legal rightsrights to recover for injuries that have already occurred. ${ }^{8}$ With respect to matured legal rights, an examination of the economics of existing sales arrangements suggests that there should be uniform regulatory treatment of settlements and third-party sales. This implies that third-party funding of matured legal rights should be treated on the assumption that it is no more harmful to society than settlement. With respect to unmatured legal rights, my examination of the economics of existing sales arrangements suggests that regulation should be based on two principles: first, that the seller should have sufficient

6. On anti-market objections to third-party litigation funding, see W. Bradley Wendel, Alternative Litigation Finance and Anti-Commodification Norms, 63 DePaul L. Rev. 655 (2014). One version of the ethically based objection holds that the sale of legal rights extends the market into areas of life in which it should play no substantial role. On critiques of the scope of markets, see Richard M. Titmuss, The Gift Relationship: From Human Blood to Social Policy (1971); Kenneth J. Arrow, Gifts and Exchanges, 1 PHIL. \& PuB. Aff. 343 (1972); Margaret Jane Radin, Market-Inalienability, 100 HARv. L. REv. 1849 (1987).

7. See, e.g., Robert G. Bone, Civil Procedure: The Economics of Civil Procedure 72 (2003) (describing and analyzing settlement as a sale to the defendant of the plaintiff's right to sue). There have been arguments lodged against settlement, see, e.g., Owen M. Fiss, Against Settlement, 93 YALE L.J. 1073 (1984), though they have typically pointed to possibly negative effects, such as a reduction in the stock of rules generated by courts, rather than the fact that settlement is effectively the sale of a legal right. In any event, the practice is so well entrenched that it is highly unlikely that any of the arguments against settlement will have any impact on its prevalence.

8. I borrow the terms "matured" and "unmatured" legal claims from Robert Cooter, Towards a Market in Unmatured Tort Claims, 75 VA. L. REv. 383 (1989). 
information on the type of purchaser to set an appropriate price, and second, that the purchaser's incentive to enforce the right should be aligned with that of the seller. These principles suggest that some restrictions on third-party funding in the context of unmatured legal rights may be socially desirable.

\section{Forms of Third-Party Funding in Litigation}

Consider a simple example that illustrates the different scenarios in which third-party funding of litigation may operate. Suppose the victim, a skier, is injured at a ski resort due to the negligence of the resort's operators. Her injuries generate a claim for damages of $\$ 50,000$. How could a third party finance the victim's claim against the ski resort?

One scenario would involve the third party purchasing the entire claim from the victim. The third party might offer the victim $\$ 20,000$ in exchange for full ownership of the tort suit. Such ownership would entail the right to appropriate the final judgment and to control the litigation. It would also entail an agreement in which the victim testifies and offers evidence on behalf of the claim in court, even though the third party would pocket the final judgment.

A second scenario, similar to the first, would involve the third party offering to finance the victim's lawsuit in exchange for all or some share of the final judgment. Notice that if the third party finances the lawsuit in exchange for all of the judgment, this scenario is not significantly different from the first. In both scenarios the third party gives the victim money up front in exchange for taking the judgment at the end. If the third party finances the lawsuit in exchange for a share of the judgment, then the third party becomes a part owner rather than the sole owner of the lawsuit.

A third scenario to consider is one in which the third party enters into a contract with the victim before the victim visits the ski resort. In this case, the third party and the victim agree that the third party will appropriate any tort judgment for the victim if the victim is injured at the ski resort. In this contract, the third party pays the victim in advance to gain ownership of her tort rights against the ski resort. A more complicated version of the same deal would involve the third party negotiating in advance of the accident for partial ownership of the final judgment.

Each of these scenarios involves some elements of risk sharing and transfer of control. The first two scenarios involve the ex post transfer or acquisition of legal rights, which is the transfer of a right to bring suit for a claim that has already materialized or matured. The third 
scenario involves the ex ante transfer of legal rights, which is the transfer of a legal claim before it has materialized or matured. In these scenarios the third party becomes a residual owner of the victim's legal claim by virtue of transferring a fixed fee to the victim and gaining, in exchange, ownership of all or part of the victim's uncertain and variable final judgment. The only difference in the outcome of the scenarios is that the victim retains part ownership of the final judgment in some and relinquishes ownership of the final judgment entirely in others. The difference between part and full ownership is a function of the degree of risk, as well as the degree of control, that the third party chooses to assume in the contract.

Transfer of control, in whole or in part, is a predictable feature of the contracts under consideration. If a third party gained ownership of the entire judgment and did not gain control over the prosecution of the victim's case, then she would have purchased something of potentially little value. In the absence of any third-party control, the victim, after selling her right to the final judgment, could choose not to enforce the right through litigation. Given such a risk, the third party would be unlikely to pay a significant amount for the right.

It bears repeating that third-party funding is, in essence, equivalent to the sale of all or a share of the final judgment of a lawsuit. It may seem at first glance that the policy issues raised by the sale of legal rights are different from the policy issues raised by the third-party financing of lawsuits. However, the economic equivalence of financing and sale implies that the policy issues surrounding the two are mostly the same.

\section{A. Law in a Nutshell}

I have not addressed the legality of any of the foregoing hypothetical scenarios; for the most part, they all raise issues of legality. Each of the scenarios would likely violate common law rules prohibiting the transfer of legal claims to third parties, generally referred to as prohibitions on maintenance, champerty, and barratry. Maintenance is the provision of financial or other support to a lawsuit. Champerty is a special type of maintenance in which the third party collects a portion of the judgment. Barratry is the practice of stirring up litigation, described as "a continuing practice of maintenance or champerty." 9

Lately, these common law prohibitions have begun to be relaxed in many jurisdictions, and accordingly, the legal issues have become

9. In re Primus, 436 U.S. 412, 424 n.15 (1978) (citing 4 BLACKSTONE, supra note 1, at *134-36). 
murky. In spite of this, the first (ex post sale) and third (ex ante sale) scenarios-in which an unrelated third party purchases the entire value of the legal claim of the victim ${ }^{10}$-would probably be prohibited, or at least unenforceable, in most jurisdictions. The more complicated scenarios in which the third party agrees to finance the litigation in exchange for a portion of the final judgment would survive scrutiny in some jurisdictions, but not all.

\section{B. Understanding Economics and Ethics}

This Article focuses on the economics and ethics of third-party funding and the legal basis for regulation. To gain insight into these issues, it is useful to consider the accepted forms under which legal rights are transferred today. Those forms are settlements, waiver agreements, and subrogation agreements. In a standard settlement, the plaintiff agrees to end her lawsuit in exchange for money from the defendant. In effect, the plaintiff sells her right to bring suit to the defendant. The difference between a settlement and a waiver is that the sale of the right to sue occurs ex post in the settlement setting, while it occurs $e x$ ante in the waiver setting. In a subrogation agreement, the potential victim sells her right to sue ex ante to a third party, typically an insurer.

The policy controversy generated by third-party funding of litigation follows more or less from the laws that restrict a third party from purchasing a legal claim either ex post or ex ante. In most jurisdictions, the ex post sale of personal tort claims to third parties is prohibited. ${ }^{11}$ The ex ante sale of personal claims is also prohibited, though an exception is made for the subrogation agreement. Are there sound reasons for these prohibitions, and are they consistent with one another in view of the underlying economics of rights transfers? To answer these questions, I will take a closer look at the economics of waiver, subrogation, and settlement agreements.

10. It is important to distinguish a claim for personal injury from a claim based on a contract. Unlike personal injury claims, contract- and property-based claims are assignable to third parties, especially matured claims concerning debt or property. See, e.g., Am. Sur. Co. of N.Y. v. Baker, 172 F.2d 689, 691-92 (4th Cir. 1949); Alcman Servs. Corp. v. Bullock, 925 F. Supp. 252, 258 (D.N.J. 1996), aff'd, 124 F.3d 185 (3d Cir. 1997); see also Myriam Gilles \& Anthony Sebok, Crowd-Classing Individual Arbitrations in a Post-Class Action Era, 63 DePaul L. Rev. 447, 474 (2014); Hylton, supra note 4, at 707.

11. See, e.g., Hylton, supra note 4 , at $702,707$. 


\section{Ex Ante Sales of Legal Rights}

Ex ante sales of legal rights exist in the form of waiver agreements and subrogation agreements. While the law views waiver agreements with suspicion, subrogation agreements are treated as socially benign. ${ }^{12}$ In order to understand the bases for these views, one should examine the economic incentives and welfare effects of such agreements.

\section{A. Basic Economics of Waiver Agreements}

Suppose that long before an accident occurs the likely injurer approaches the likely victim and asks the victim to waive her right to bring a tort suit against the injurer. How much will the victim demand in compensation for selling her tort claim? If the victim sells her right to sue the injurer, the injurer will no longer have a need to take care in order to avoid liability. Thus, the victim knows that once she has waived her right she will face a greater risk of being harmed by the injurer.

To simplify, assume that liability is strict. The victim will be compensated for the harm she suffers if she retains her right to sue, whether or not the injurer takes care. Thus, the expected incremental harm to the victim, as a result of selling her tort claim to the injurer, is simply the probability that the injurer will injure her (when the injurer does not take care) multiplied by the loss from injury. If the victim did not sell her tort claim, her expected injury loss would be zero because she would receive full compensation under strict liability.

However, if the victim waives her right to sue, she gains the benefit of not bearing the cost of bringing suit. Taking into consideration the costs and the benefits of a waiver, the victim will need to be compensated for the expected injury due to the injurer's lack of care, less the expected cost of suing to collect damages when the injurer does take care. For example, suppose the probability of injury when the injurer does not exercise care is .75 , and the probability of injury when she does take care is .25 . If the victim's loss is $\$ 50,000$ and the litigation cost is $\$ 20,000$, the minimum payment that the victim will require in order to waive her right to sue the injurer is $(.75 \times \$ 50,000)-(.25 \times$ $\$ 20,000)=\$ 32,500$. Generally, if $P$ is the probability of injury when the injurer does not take care, $Q$ the probability of injury when the injurer does take care, $L$ the victim's loss, and $C_{p}$ the victim's litigation

12. Reuben Hasson, Subrogation in Insurance Law - A Critical Evaluation, 5 OXFORD J. LEGal Stud. 416, 416 (1985). 
cost, the victim will sell her right to sue in tort for any payment greater than $P L-Q C_{p}$.

What will the injurer be willing to pay for a waiver from the victim? In the absence of such a waiver, the expected cost of the plaintiff's tort right to the injurer is equal to the sum of the cost of liability when she takes care, the cost of litigation when she takes care, and the cost of taking care. The injurer will purchase the plaintiff's tort right for any sum of money that is less than the expected cost of the plaintiff's tort right. Continuing with the assumption of the example in the previous paragraph (specifically, that the probability of injury to the victim is .25 when the injurer takes care), if the cost of taking care is $\$ 16,000$, the expected cost to the injurer of the plaintiff's tort right is equal to $\$ 16,000+(.25 \times \$ 50,000)+(.25 \times \$ 20,000)=\$ 33,500$. Generally, if $B$ represents the cost of taking care and $C_{d}$ the cost of litigation for the injurer, then the expected cost of the plaintiff's tort right to the injurer is $B+Q L+Q C_{d}$.

Waiver agreements will occur when the price the victim demands to sell her right to sue is less than the amount the injurer is willing to pay to purchase the victim's right. ${ }^{13}$ Under the previous numerical assumptions, the parties would enter into a waiver agreement because the defendant would pay up to $\$ 33,500$ for the victim's tort right and the victim would be willing to sell it for $\$ 32,500$.

Waiver agreements eliminate tort litigation in settings where such litigation would reduce society's welfare. The benefit to society of tort litigation is equal to the injuries avoided because of the deterrent threat of litigation, less the cost of avoiding those injuries. ${ }^{14}$ The cost of tort litigation is the total amount spent on litigation. ${ }^{15}$ Litigation reduces society's welfare when the deterrence benefit is less than the total cost of litigation. ${ }^{16}$ Whenever this is true, the potential victim and potential injurer will have an incentive to enter into a waiver agreement. ${ }^{17}$

All of this assumes a high degree of sophistication on the part of the victim and the injurer. If this assumption is relaxed, one can find circumstances in which a waiver agreement may not be beneficial for society. For example, if the victim cannot set a proper price for the

13. Using the general terms introduced in the text, the price the victim demands is less than the price the injurer is willing to pay when $P L-Q C_{p}<B+Q L+Q C_{d}$.

14. Using the general terms, the deterrence benefit is $P L-Q L-B$.

15. The expected litigation cost is $Q C_{d}+Q C_{p}$.

16. Again, using the general terms, $P L-Q L-B<Q C_{d}+Q C_{p}$.

17. The social welfare condition, $(P-Q) L-B<Q\left(C_{d}+C_{p}\right)$, and the waiver condition, $P L-$ $Q C_{\rho}<B+Q L+Q C_{d}$, are the same. See Keith N. Hylton, Agreements to Waive or to Arbitrate Legal Claims: An Economic Analysis, 8 Sup. CT. Econ. Rev. 209, 213 (2000). 
waiver, she may sell the waiver under conditions that reduce society's welfare. Lack of sophistication on the part of likely victims may provide a justification for refusing to enforce waiver agreements in some cases. If the lack of sophistication is both severe and widespread, a policy of prohibiting tort waivers may be socially desirable.

\section{B. Basic Economics of Subrogation Contracts}

In a subrogation agreement, a party that compensates the victim for her loss gains the right to pursue the injurer for the amount that the party has paid to the victim. In the typical subrogation contract, a medical insurer that has agreed to pay for the medical expenses of the insured gains the right to sue the injurer for those expenses. To simplify matters, I will assume that the subrogating entity sues for the entire loss suffered by the victim-that is, that the victim suffers no losses above and beyond the amount covered by the subrogation agreement. The subrogation agreement requires the prospective victim (the insured) to sell her right to sue in tort, just as the waiver agreement does. However, the difference between the subrogation agreement and the waiver agreement is that the subrogation agreement involves a sale to a party who generally will enforce the tort right, ${ }^{18}$ while the waiver agreement involves the extinguishment of the tort right. Because of this difference, the likely victim will sell her tort right to the subrogating entity for a different price-a lower price than she would sell under a waiver agreement.

One benefit the victim gains from a subrogation agreement, which also provides a reason for her to enter into such an agreement, is that she avoids the burden of having to pay to litigate if she becomes the victim of a tort. ${ }^{19}$ The victim transfers her claim to damages to the subrogating entity. Since the subrogating entity maintains the threat to sue in tort, the injurer will have an incentive to continue to exercise care after the subrogation agreement comes into effect. Thus, the victim will sell her right to sue to the subrogating entity for an amount equal to the expected injury she would suffer, given that the injurer takes care, less the expected cost of litigation, $Q L-Q C_{p}$.

18. To be sure, the promise to enforce the tort right is not open ended. If the value of the tort claim is less than the expense of litigating, the subrogating entity may choose not to litigate, just as the victim herself might choose not to litigate a small claim.

19. This statement reflects my simplifying assumption that the subrogation contract covers all of the losses that the victim suffers. This is not an accurate description of the typical subrogation agreement. A medical insurer that compensates for medical expenses only will not gain a contractual right to sue for non-medical expenses, such as lost wages. 
If the subrogating entity can litigate less expensively than the victim can, then both the victim and the subrogating entity may benefit from the transfer of the victim's tort right to the subrogating entity. For example, the subrogating entity may be able to litigate less expensively than the victim because it is a repeat player in litigation, while the likely victim has never been to court. Thus, if the subrogating entity's cost of litigation is $C_{s}$, where $C_{s}<C_{p}$, then the subrogation contract will be mutually beneficial, because the value of the victim's tort right to the subrogating entity, $Q L-Q C_{s}$, will exceed the value of the tort right to the victim, $Q L-Q C_{p}$.

In the case where the cost of bringing suit is prohibitive to the victim, the subrogation option enables tort law to maintain its capacity to deter tortious conduct. In the absence of the subrogation option, the victim would not have a credible threat to sue, and the injurer would therefore not have an incentive to take care. For example, suppose that the probability that the injurer will injure the likely victim is .25 when the injurer is taking care. Further, assume that liability is strict. The value of the potential lawsuit to the likely victim is $(.25 \times \$ 50,000)$ $-(.25 \times \$ 20,000)=\$ 7,500$. If the cost of litigation for the subrogating entity is $\$ 1000$, then the value of the victim's potential lawsuit in the hands of the subrogating entity is $(.25 \times \$ 50,000)-(.25 \times \$ 1000)=$ $\$ 12,250$. This implies that the subrogating entity will be willing to pay the likely victim an amount of money greater than the value of the tort right to the victim in order to gain ownership of that right. For example, the medical insurer might offer a discount on insurance coverage in order to share part of the value of the subrogation right with the likely victim.

\section{Importance of Identity of Purchaser of Ex Ante Right}

In the previous subparts, I considered the economics of selling $e x$ ante rights to the likely defendant (waiver) and to an insurer (subrogation). Notably, the law permits both types of rights transfer, but with heavier restrictions on waivers. ${ }^{20}$

In the case of a waiver, the price that a potential victim would put on the sale of her ex ante right to sue is equal to the expected harm, given the injurer does not take care, less the expected cost of litigation in the scenario where she retains the right to sue. In the case of a subrogation agreement, the price that a potential victim would put on

20. The restrictions on waivers come in the form of public policy rules and rules on enforceability of contracts (e.g., the unconscionability doctrine). On the public policy restrictions, see Tunkl v. Regents of Univ. of Cal., 383 P.2d 441, 443-46 (Cal. 1963). 
the sale of her right to sue to the subrogating entity is equal to the expected harm less the cost of litigation, all estimated under the assumption that the threat to sue remains in force and that the injurer therefore takes care. Since the expected harm to the victim is lower when the injurer takes care, the price demanded by the victim to transfer her right to sue is unambiguously higher in the case of a waiver agreement than in the case of a subrogation agreement.

It follows that the identity of the purchaser is extremely important in the context of an ex ante sale of legal rights. A sale to an injurer is much riskier for the potential victim than a sale to a subrogating entity. If the potential victim cannot be sure that she is selling to a subrogating entity, her rational strategy would be to assume that she is waiving her right to sue whenever she sells that right. It seems rational victims would sell their rights mostly to injurers, since injurers would make up the lion's share of the parties willing to pay the price demanded by the victim. Due to this fact, an adverse selection spiral21 would probably arise in which the market for ex ante rights withered.

The difference between waiver contracts and subrogation contracts can be expanded upon to include the ethical dispositions of attorneys as potential purchasers of $e x$ ante legal rights. The incentives of a subrogating entity do not differ from those of a lawyer who honestly represents the victim. If a lawyer were to purchase the victim's legal right ex ante, she would offer the same price as a subrogating entity. A lawyer who is conflicted, in the sense that she is really the agent of the injurer, would offer the same price for the victim's right as would the injurer. The danger created by such a conflict, in which the lawyer who purchases the victim's ex ante right is really the agent of the injurer, is that such a lawyer will offer a price $\left(B+Q L+Q C_{d}\right)$ that is greater than that offered by the faithful lawyer $\left(Q L-Q C_{s}\right)$. The victim who is unaware of the conflict would find that faithless lawyers bid more for control of her rights ex ante than do faithful lawyers.

\section{Ex Post Sales of Legal Rights}

The most common ex post sale of legal rights observed today is the settlement. However, various contract rights, such as debt claims, are also transferred to third parties. Since such contract claims have fully materialized, in the sense that the debtor definitely owes a certain sum of money to the creditor, they should also be considered examples of ex post sales of legal rights.

21. For a description of how adverse selection spirals are created, see Michael Abramowicz, On the Alienability of Legal Claims, 114 YALE L.J. 697, 743 (2005). 


\section{A. Basic Economics of Settlement}

I now consider the basic economic model of settlement and its implications for the transfer of legal rights to third parties. To the plaintiff, the value of the ex post right to sue is equal to the plaintiff's expected judgment less the plaintiff's litigation cost, where the expected judgment is the product of the plaintiff's estimate of her probability of winning and the value of the damage award. It follows that if $W_{p}$ represents the plaintiff's estimate of her likelihood of winning in court, the value of the ex post suit right to the plaintiff is represented by $W_{p} L-C_{p}$. For the defendant, the maximum that she is willing to pay to gain ownership of the plaintiff's ex post right to sue is the total financial burden the defendant would bear if the plaintiff sues, which is the expected liability plus the defendant's cost of litigation. Thus, if $W_{d}$ represents the defendant's estimate of the plaintiff's likelihood of winning in court, the maximum the defendant will pay for the plaintiff's right is $W_{d} L+C_{d}$. A settlement will occur if the amount the defendant is willing to pay for the plaintiff's right exceeds the plaintiff's valuation of this right, $W_{p} L-C_{p}<W_{d} L+C_{d}$, or equivalently if the total settlement surplus, $S=C_{p}+C_{d}+\left(W_{d}-W_{p}\right) L$, is positive. As a general rule, the greater the surplus, the more likely settlement is. ${ }^{22}$

Settlement generates wealth in two ways: by eliminating expenditures on litigation and by transferring an asset (the right to sue) to the party who places the highest value on it. If the defendant thinks that the plaintiff is more likely to win than does the plaintiff herself (i.e., $W_{d}>W_{p}$ ) then settlement effectively transfers the right to sue to the party who values it the most. The potential welfare gain from settlement is therefore the sum of the litigation costs (avoided through settlement) and the differential between the defendant's and the plaintiff's valuations of the right to bring suit. If the plaintiff values the right to sue more than the defendant, settlement can still create wealth as long as the litigation costs avoided are greater in total than the difference in the parties' valuations of the suit right.

What happens if the plaintiff sells her ex post right to sue to a third party? The third party will purchase the plaintiff's right only if her valuation of the right is greater than the plaintiff's. This scenario could result if the third party's estimate of the likelihood of winning is

22. This is a convenient assumption often adopted in the literature on settlement. However, the assumption is not necessarily correct in every instance. Robert Bone notes that the size of the bargaining surplus may not be positively correlated with the probability of settlement--litigants may adopt "hard bargaining" strategies that make settlement less likely as the surplus expands. See BONE, supra note 7 , at $78-85$. 
greater than the plaintiff's or if the third party's cost of litigation is lower than the plaintiff's. The potential welfare surplus from transfer is equal to the sum of the differential in litigation costs and the differential in claim valuations. Thus, if $\tilde{W}_{p}$ and $\tilde{C}_{p}$ represent the third party's win prediction and litigation cost respectively, the surplus from transferring the right to sue to the third party is $C_{p}-\tilde{C}_{p}+\left(\tilde{W}_{p}-W_{p}\right) L$. Generally, if the transfer surplus is positive, the plaintiff will sell her right to the third party.

As an aside, note that this presentation of the incentive to transfer an ex post claim to a third party is also a description of the lawyer-client relationship; the lawyer, in effect, purchases the ex post right to sue from the client. The client could bring the suit on her own, pro se, but the lawyer can do so at a lower cost and with a higher win probability. In the typical contingency fee arrangement, the lawyer agrees to pay a share of the judgment, often two-thirds, to the client in exchange for control over the client's claim.

In some settings the victim will be willing to settle her lawsuit while the third party will want to litigate. Indeed, as long as the win probabilities are not changed by the rights transfer, any time a mutually beneficial sale occurs between a plaintiff and a third party (positive transfer surplus), the third party will be more likely to litigate than would the plaintiff if she had held on to her right. Thus, sales to third parties will generally lead to a greater frequency of litigation. The reason is easy to demonstrate in the basic settlement model. A mutually beneficial sale to a third party implies that the settlement surplus will fall after the sale. Given that the initial settlement surplus when the victim retains the right to sue is $C_{p}+C_{d}+\left(W_{d}-W_{p}\right) L$, and the settlement surplus after transfer to the third party is $C_{p}+C_{d}+\left(W_{d}\right.$ - $\left.\tilde{W}_{p}\right) L$, the initial settlement surplus exceeds the post-transfer settlement surplus as long as the transfer surplus is positive $\left(C_{p}-\tilde{C}_{p}+\left(\tilde{W}_{p}-\right.\right.$ $\left.W_{p}\right) L>0$ ). Thus, as long as the transfer of the ex post right to the third party is mutually beneficial, the settlement surplus will fall after the transfer, making settlement less likely to occur.

Will social welfare be enhanced or reduced when a victim who would otherwise settle sells her ex post right to a third party who litigates? This is of immediate concern in the third-party-financing literature because opponents of third-party litigation financing have said that it might lead to more frequent litigation, with the implication that this is an undesirable outcome. The important question, of course, is whether social welfare will be enhanced in such cases. The following proposition is an implication of the economic model of settlement: As long as the rights transfer does not affect the win probabilities, social 
welfare is unambiguously greater when the victim sells her ex post right to the third party.

Support for this claim is easily demonstrated within the settlement model. The case in which the victim would settle while the third party would litigate is where the settlement surplus is positive as between the victim and the defendant $\left(C_{p}+C_{d}+\left(W_{d}-W_{p}\right) L>0\right)$, which means that society's wealth can be enhanced by the victim settling, and the settlement surplus is negative as between the third party and the defendant $\left(\tilde{C}_{p}+C_{d}+\left(W_{d}-\tilde{W}_{p}\right) L<0\right)$, which means that social wealth cannot be enhanced by the third party settling. If the victim held on to and settled her tort right, social wealth would be enhanced from the settlement. If, however, the victim sells her tort right to the third party, social wealth would be enhanced both by the sale and by the third party's refusal to settle. The wealth generated by the sale (transfer surplus) is $C_{p}-\tilde{C}_{p}+\left(\tilde{W}_{p}-W_{p}\right) L$, and the wealth generated by the refusal of the third party to settle is $\left(W_{p}-W_{d}\right) L-C_{p}-C_{d}$. Sale to a third party who litigates is socially preferable to the victim retaining (and settling) her claim if the wealth generated by the sale and the third-party lawsuit (together) is greater than the wealth generated by the victim's settlement: $C_{p}-\tilde{C}_{p}+\left(\tilde{W}_{p}-W_{p}\right) L+\left(\tilde{W}_{p}-W_{d}\right) L-\tilde{C}_{p}-C_{d}$ $>C_{p}+C_{d}+\left(W_{d}-W_{p}\right) L$. This condition holds as long as the settlement surplus is negative (i.e., settlement is not mutually beneficial) between the third party and the injurer, which is one of the premises of this argument. Thus, viewed from an ex post perspective, society's wealth is enhanced when a victim who would settle sells her right to a third party who litigates.

It is important to note that this is an examination of welfare effects in the market for ex post rights. This discussion leaves out the implications of settlement for ex ante incentives. A settlement might generate wealth in the ex post rights market but at the same time dilute ex ante incentives to take care by reducing the total amount of damages imposed on the injuring party. Conversely, a transfer to a third party may enhance wealth in the ex post rights market while at the same time generating incentives for socially excessive care. A comprehensive welfare analysis would balance the welfare implications of ex ante incentive effects with the wealth generated by rights transfers in the $e x$ post rights market.

One of the most important, if not the most important, points to note about the ex post sale of legal rights is that the plaintiff's valuation of her right to sue is independent of the identity of the purchaser. For the original plaintiff, the value of her ex post right to sue is equal to the expected net payoff from a lawsuit-the plaintiff's expected judg- 
ment less the plaintiff's cost of litigation. This valuation remains the same no matter who proposes to purchase the right from the plaintiff.

\section{Policy Concerns}

The foregoing discussion reveals a fundamental difference between ex ante and ex post sales of legal rights. In the ex post setting, the price that a holder of a legal right would set in order to transfer it to a third party is independent of the identity of the third party. In the ex ante setting, the price the holder would charge in order to transfer a legal right to a third party is dependent on the identity of the third party since selling to the injurer is not the same as selling to a subrogating entity.

This difference has two important policy implications. First, there appears to be no economic justification for prohibiting ex post sales to third parties, or for putting special regulations on ex post sales that go beyond what the law already places on settlement agreements. Second, sales to third parties of $e x$ ante rights should be treated differently from sales of ex post rights in a regulatory framework for rights markets.

\section{A. Equivalence of Settlement and Sales}

If the law permits a plaintiff (victim) to settle her case, which is selling her ex post legal right to the defendant (injurer), it would seem strange for the law not to permit the plaintiff to sell her right to a third party who may value it more than the defendant. However, this is the state of the law in the majority of jurisdictions, though it is poorly enforced. What reasons could there be for such a distinction in permissible contracts?

One possible reason for prohibiting sales of ex post rights to third parties is that the plaintiff may be too uninformed to enter into a mutually beneficial contract. To be sure, the plaintiff may not know the value of a legal right ex post. A person who suffers a slip and fall may not be able to set a price on her tort claim against the property owner. This might seem to present a problem in a regime in which rights are transferred to third parties, but it is a problem that already exists in the settlement context. If the plaintiff has a good lawyer, that lawyer will help her determine the price of her ex post right to sue, whether that price is charged to a third party or to the injurer in a settlement. Indeed, one could say that the market for lawyers is differentiated primarily on the basis of the degree of skill that a lawyer brings to the determination of a price for an ex post right to sue. Lawyers are 
clearly capable of bringing the same skills to bear on the question of whether a plaintiff should sell her right to a third party, rather than to the defendant in a settlement. Permitting plaintiffs to sell their ex post rights to third parties might create an auction market for legal rights, permitting plaintiffs to receive the highest compensation amounts on average, and allowing for society's wealth to be enhanced by the transfer of the suit right to the party who values it the most.

As Michael Abramowicz notes, sales of ex post claims could generate an adverse selection phenomenon, ${ }^{23}$ which might provide a justification for prohibition. Plaintiffs with low-value claims would be quick to sell them while plaintiffs with high-value claims would tend to hold on to them. Any bid offered for a pool of claims would generate sales mainly from victims whose claims are considerably less than the value of the bid. The market would spin into an adverse selection spiral, and eventually disappear. In this justification for prohibition, the informational disadvantage of potential third-party purchasers is the key problem rather than the informational disadvantage of potential sellers (victims).

However, there are features of the legal market that would tend to reduce the likelihood of an adverse selection spiral. Respected lawyers, who would need to protect their reputations, would not attempt to make a short-term profit by selling off low-value claims on arguably fraudulent terms. The need to gain repeat business would discourage them from being the facilitators of an adverse selection spiral. Moreover, even if such a spiral were to occur, its effect would be to reduce the size of a market, closing off a set of potentially wealth-enhancing trades, without directly harming the owners of legal rights. In other words, if the adverse selection problem were to materialize, its effect on social welfare would be limited in a manner similar to the loss in social welfare that results from monopolization. In the monopolization setting, society loses from the absence of trades that would occur in a competitive market, but society still gains from the trades that the monopolist makes. In the same sense, the adverse selection spiral would close off some potential trades that would enhance society's welfare, but some welfare-enhancing trades would still occur.

23. Abramowicz, supra note 21 , at 702 . The adverse selection problem Abramowicz emphasizes results because of private information of prospective victims, who know the potential value of their claims better than others do. Id. The adverse selection problem is also the source of Abramowicz's reform proposals in his contribution to this symposium. See Michael Abramowicz, Litigation Finance and the Problem of Frivolous Litigation, 63 DePAul L. REv. 195 (2014). 
Although this argument is framed in terms of the sale of legal rights, the implications apply directly to the financing of lawsuits by third parties. Third-party funding of litigation introduces the phenomenon of rights ownership by third parties. Indeed, a contract in which a third party agrees to finance a lawsuit in exchange for all or a share of the judgment is equivalent to a sale of the legal right, or a share of the legal right, in exchange for an up-front payment. Sales and financing agreements are indistinguishable in terms of their economic implications. ${ }^{24}$

\section{B. Distinguishing Ex Ante and Ex Post Sales}

The second policy implication of this analysis is that sales (to third parties) of ex ante rights should be distinguished from the sales of $e x$ post rights in any attempt to design a regulatory framework for rights markets. The price a rights holder would charge to transfer her $e x$ ante right to a third party depends on the identity of the third party. An individual who transfers an unmatured tort claim would want to charge different prices to a subrogating entity than to the potential injurer. If the rights holder sells to the potential injurer, unaware of the purchaser's identity, the result will be a loss in deterrence because the potential injurer will extinguish the right. The loss in deterrence may be socially undesirable, given the absence of an informed trade of rights. Unlike the ex post transfer market, inefficient transfers in the ex ante rights market could result in a greater frequency of negligent injury to tort victims.

This suggests that there is an economic case for regulation of the transfers in a market in ex ante rights. Regulation should be based on two principles: that the seller (victim) should know the identity of the purchaser (i.e., whether the purchaser is an injurer or subrogating entity), and that the purchasing third party (if it is not the injurer) should have incentives that are aligned with those of the victim. The reason for requiring that the victim know the identity of the purchasing third party is a straightforward implication of the preceding arguments. If the victim does not know the identity of the purchasing third party, then she may mistakenly sell her ex ante rights to a third party that she

24. There is a level of analysis, which is not carried out in this model, in which sales and financing arrangements might generate different incentives, and here I am referring to agency costs. Still, the basic principle that sale and financing permit rights to be transferred to parties who value them most implies that agency costs are likely to be lessened. On agency costs and financing of legal claims, see Ronen Avraham \& Abraham Wickelgren, Third-Party Litigation Funding-A Signaling Model, 63 DEPAUL L. Rev. 233 (2014); Samuel Issacharoff, Litigation Funding and the Problem of Agency Cost in Representative Actions, 63 DePaul L. Rev. 561 (2014). 
thinks is committed to enforcement, when the third party is in fact the injurer or the alter ego of the injurer.

Having the incentives of the third party aligned with those of the victim is necessary in order to prevent instances in which the third party sells, to the injurer, the legal right that she has acquired from the victim. Such a sale, of course, is equivalent to a waiver of the victim's right, executed by a third party. In a regime in which any third party can purchase the ex ante rights from the victim, there is a possibility that the third party's incentives to sell may deviate from the incentives of the victim.

The incentive deviation problem arises because even though the third party owns the victim's legal right, she will not necessarily suffer from the consequences of selling the right, specifically where the sale amounts to a waiver. If the third party sells the legal right of the victim to the injurer, she will suffer no harm from doing so. However, the victim will suffer the harm from such a sale. Given this difference, the possibility that the third party may waive the victim's rights in an inefficient transaction is much higher than the possibility that the victim herself would inefficiently waive her rights.

Looking more closely at the problem, the key distinction is that the potential torts that arise when the victim's rights are waived represent a real harm to the victim, but they represent only an opportunity for additional compensation-i.e., an opportunity cost-to the third party. If the third party, as rights holder, consistently sets a price on the victim's rights that fully reflects the opportunity cost of those rights under the waiver regime, then there will never be a divergence between the incentives of victims and third-party rights holders. But there is no guarantee that the third party will always take the opportunity costs of the victim's rights into account. The third party may sell the rights at a discount, perhaps because the third party is unaware of the opportunity cost, is under financial pressure to generate cash, or is trading away profit for market share.

The only simple way to avoid the incentive divergence problem is to follow the pattern of the existing arrangements in which third-party rights holders own the $e x$ ante legal rights of potential victims. These existing models are the subrogation contract and the patent troll. ${ }^{25}$ In the case of a subrogation contract, the subrogating entity's incentives do not diverge from those of the victim because the subrogating entity is contractually bound to compensate the victim for all or a substantial

25. Patent trolls essentially purchase ex ante rights to enforce patents. On patent trolls and third-party litigation funding, see Hylton, supra note 4, at 722-23. 
share of the victim's injuries. Given this contractual commitment, the subrogating entity generally does not have an incentive to waive the victim's rights in exchange for an inadequate price because the entity has to compensate the victim anyway.

The other existing case of third-party ownership of ex ante rights is that of the patent troll. The patent troll typically buys the patent itself, not just the right to sue for infringement. By taking ownership of all or a substantial part of the patent, the patent troll aligns her incentives with those of the original patent holder. The original inventor need not worry that the troll will inefficiently waive the right to enforce the patent.

These examples suggest that the proper regulatory approach to third-party transfers in ex ante rights would limit enforcement of such transfers to instances in which either the third party has entered into something akin to a subrogation agreement with the victim, ${ }^{26}$ or the third party has purchased from the victim an asset whose value would be put at risk by the waiver of rights. Under such arrangements, the third party's incentives to trade the rights that it has purchased would not deviate strongly from those of the original rights holders. If the third-party rights holder does not have an obligation to compensate (as in the traditional subrogation relationship) or does not own an asset that would be put at risk by the waiver of rights, one appropriate regulatory approach would be the adoption of a judicial policy barring enforcement of any agreement by the original victim to transfer her $e x$ ante rights in such cases. Thus, in the scenario in which the victim transfers her rights to a third party who then inefficiently waives those rights, the victim would regain the right to sue. This approach has the virtue of simplicity. The victim would be able to enforce the right on her own without requiring the maintenance of a regulatory agency.

\section{Concluding Remarks}

Since third-party financing of lawsuits is equivalent in economic terms to the sale of legal rights to third parties, this Article has focused primarily on sales and their associated incentive and welfare effects. My claim that there is no sound economic basis for a blanket prohibition of the ex post sales of legal rights to third parties implies that there is no sound economic basis for a blanket prohibition of the third-party financing of matured legal claims. Rather than basing my argument on an overall welfare analysis of litigation in the presence of

26. Robert Cooter proposed a market in unmatured tort claims that is equivalent, in operation, to an expansion of subrogation markets. See Cooter, supra note 8, at 383-84. 
third-party sales, I have argued that if society permits settlements to occur without heavy-handed regulation, then it should permit thirdparty sales of ex post rights to occur too, on the same basis. However, if a welfare analysis indicated that settlement should be prohibited in a particular setting, then the same analysis might show that third-party sales of ex post rights should also be prohibited under the same conditions.

The sale of ex ante legal rights is a more complicated issue, given that inefficient transfers can have harmful consequences to potential tort victims. In view of this risk, there is a strong case for ensuring that $e x$ ante rights transfers do not result in potential tort victims waiving their legal rights unknowingly. A market in which expanded subrogation contracts are encouraged, or where a greater variety of rights-assertion entities (similar to patent trolls) exist, should easily avoid the risks associated with a market in ex ante legal rights. 
